\title{
MEASUREMENT OF VERTICAL FISCAL IMBALANCE
} IN GERMANY

Regional inequalities are currently a challenge for the majority of countries, in particular large ones, some of which are federations. The federal state system is more complex than the unitary system. This results in specific problems. One of them is the issue of the differing level of economic development of individual territorial units, where the problem of income redistribution emerges. The difference between income and expenses results in the formation of fiscal gaps, both horizontal and vertical. The aim of the paper is to make an attempt to review the literature and to present the measures applied for measuring the vertical fiscal imbalance. It is also the starting point for conducting measurements of those imbalances in Germany based on Bird's and Tarasov's methodology. The paper presents the measures applied in the literature for the purposes of measuring vertical fiscal imbalance. In addition, the measurement of those imbalances in Germany are presented.

Keywords: fiscal imbalance, fiscal gap, measures of vertical inequalities, vertical fiscal imbalance, regional inequalities, federal-regional transfers

JEL Classifications: H72, H73, H74, H77, O12, R12

DOI: $10.15611 /$ aoe.2016.2.05

\section{INTRODUCTION}

The decentralization of public finances coupled with the state federal structure results also in the emergence of specific problems and subsequently their solution, apart from the benefits. The main problem is the decentralization of the tax authority and financial equalization. Due to the possible differentiation of the economic development level of the territorial units of a federation, the problem of public income redistribution emerges both horizontal and vertical. The most often considered one is the vertical distribution of income between individual levels of the public authority. Fiscal imbalance seems to be closely correlated with the federal system. Usually federal governments tend to collect the majority of taxes, while regional and local authorities, in accordance with the principle of subsidiarity, are responsible for the majority of expenses, which can be financed from the income that is directly under their control. The result of the difference of the expenses and own income at different levels of state

\footnotetext{
* Department of Public and International Finance, Wrocław University of Economics
} 
administration is vertical fiscal imbalance, a vertical fiscal gap ${ }^{1}$. It can be said that this means the difference between the possibility to achieve income and the need of expenses at different levels of authority in a federation. The amount of the vertical fiscal gap depends on both the decisions of regional and local governments and the federal government, with the federal government playing the key role here. As described by R. Boadway and J.F. Tremblay, a vertical fiscal imbalance indicates a situation where the amount of transfers made by the federal government in favour of the regional and local authorities is far from the amount of proceeds from federal taxes in relation to their expenses (Boadway, Tremblay 2006, p. 1).

The issues of fiscal imbalance encourage the comparative research of states, especially those with a federal form. According to M. Bitner and K. S. Cichocki, comparative research on local government subsector finance is particularly rare in public finance literature (Bitner, Cichocki 2012, p. 6).

There are no up-to-date measurements and comparisons of vertical fiscal imbalance between countries. The results obtained by the end of the $20^{\text {th }}$ century can be found in English-language literature. Vertical fiscal imbalance was measured by R. Bird and A. V. Tarasov, who obtained results for eight countries, including Germany and the USA in the period 19701999 (for certain countries the last measurement year was 1997) (Bird, Tarasov 2002, pp. 36-51), and by A. Shah, who performed measurements for more than ten countries in the 1980s (Shah 1991, p. 86; Shah 1994, pp. 41-42; Shah, Qureshi 1994, p. 53).

The vertical fiscal imbalance requires that income sources assigned to the central and regional authority should be equal to the obligatory expenses. The vertical fiscal imbalance is presented in Figure 1. It occurs when the obligatory expenses assigned to each level of authority are not covered by the available funds.

The most frequent source of vertical imbalance is the lack of own income. There are several reasons for which the central authority is reluctant to assign significant income sources to regional and local authorities (Martinez-Vazquez, Boex 1999, p. 9):

- the central authority may fear the loss of control over the fiscal policy as a tool of fiscal management,

- the need of the centralized administration of the majority of taxes,

- assigning the most flexible income sources to the central level (despite the fact that local governments are often assigned the responsibility for public services with a more flexible demand in terms of income),

\footnotetext{
${ }^{1}$ The two notions are used interchangeably.
} 
- fear of mismanagement or tax competition between local authorities,

- or simply the prevailing political authority of the central government. In order to make the formulas clear, their designations were standardized.

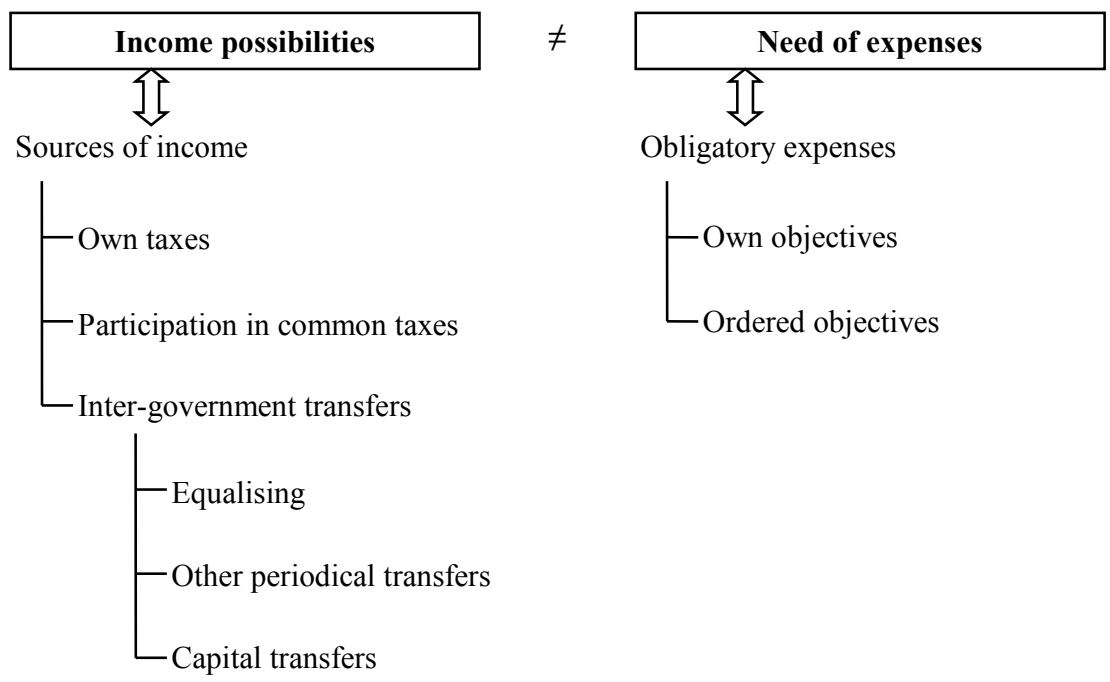

Fig. 1. Vertical fiscal imbalance

Source: own work based on (Martinez-Vazquez, Boex 1999, p. 9).

As proposed by R. Bird and A. V. Tarasov, a vertical fiscal imbalance is measured simply as the relation of transfers to regional and local expenses and it is easy to calculate. In addition, if borrowings are excluded, it may provide a useful measure of the current level of vertical fiscal imbalance in a country in a given year regarding cash flows. This measure does not specify the degree to which transfers, other income, and even expenses at regional and local level reflect the political decisions taken at federal or regional and local level (Bird, Tarasov 2002, p. 3). Due to this problem, attempts are constantly made to create improved measures of vertical fiscal imbalance. One of the first developed measures was the coefficient of vertical imbalance proposed by J. S. H. Hunter $(1974,1977)^{2}$, and the index of subnational autonomy ${ }^{3}$ aimed at measuring the degree of the control exercised by the federal government over authorities at lower levels.

\footnotetext{
${ }^{2}$ Hunter's assumptions have been challenged, yet variants of his approach are used in the literature (Bird, Tarasov 2002, p. 3).

${ }^{3}$ Term proposed by A. Shah (Shah 1994, p. 40).
} 


\section{MEASURES OF VERTICAL FISCAL IMBALANCE}

J. Martinez-Vazquez and J. Boex propose two approaches to measuring vertical fiscal imbalance. The first could be a deficit or surplus of each consolidated authority level before including borrowings, but after including common income and transfers (Martinez-Vazquez, Boex 1999, p. 10). The second approach is the coefficient of vertical imbalance $\left(\mathrm{CVI}_{1}, \mathrm{CVI}_{2}, \mathrm{CVI}_{3}\right)$ which can be calculated based on formulas developed by J. MartinezVazquez, J. Boex as well as L. Schroeder and P. Smoke (Martinez-Vazquez, Boex 1999, pp. 11-12; Martinez-Vazquez, Boex 2001, p. 48; Schroeder, Smoke 2003, p. 34):

or

$$
C V I_{1}=1-\frac{R_{S N G}^{*}}{E_{S N G}}=1-\frac{R_{S H}+G e+G o}{E_{S N G}},
$$

$$
C V I_{2}=1-\frac{G e+G o}{E_{S N G}}
$$

or

$$
C V I_{3}=1-\frac{G o}{E_{S N G}} .
$$

where: $C V I$ - coefficient of vertical fiscal imbalance,

$R_{S N G}^{*}-$ total subnational resources not under subnational control,

$E_{S N G}$ - total subnational expenditures,

$R_{S H}$ - common income,

$\mathrm{Ge}$ - equalizations transfers,

Go - other transfers.

W. Hettich and S. L. Winer developed a model of public choice in order to determine the division of funds between the federation and regional authorities plus private sector. While determining vertical fiscal imbalance they compared the relative sizes of the federal and regional public sectors as part of the existing regulations in a situation which exists within a standard reference $^{4}$ (see more Hettich, Winer 1986).

Another scholar who presented a method of measuring vertical fiscal imbalance was A. Shah. He proposed the following formula (Shah 1991, p. 86):

\footnotetext{
${ }^{4}$ This reference was the Lindhal equilibrium, achieved when all proposals as to federal expenses and "non-federal" goods are combined with all the possible formulas of tax division in relation to the entire country.
} 


$$
\begin{aligned}
& C V I=1-\frac{I G+Z N}{E}, \\
& Z N=-(R+G-E),
\end{aligned}
$$

where: $I G-$ transfers (grants from other levels of government),

$Z N$ - net borrowing,

$E$ - expenditure (total expenditure + lending - repayments),

$R$ - revenues,

$G$ - grants,

or formula (Shah 1994, p. 42; Shah, Qureshi 1994, p. 53):

$$
C V I=1-\frac{G_{S P_{S N G}}+G_{G P_{S N G}}+R_{S H}+L_{S N G}}{E_{S N G}},
$$

where: $G_{S P_{S \backslash G}}-$ specific-purpose central transfers to subnational

$G_{G P_{S V G}}-$ governments,

$L_{S N G}-$ general-purpose central transfers to subnational governments, borrowing by subnational governments.

Ch. Wallich, in turn, proposed the following formula (Wallich 1982, p. 17):

$$
C V I=1-\frac{a_{1} R w_{T}+a_{2} T_{S H}+a_{3} R w_{n T}+a_{4} G u+a_{5} G c+a_{6} L}{E},
$$

where: $R w_{T}-$ own tax revenue,

$T_{S H}$ - shared taxes,

$R w_{n T}$ - own non-tax revenue,

$G u$ - unconditional grants from central government,

$G c$ - conditional grants,

$L \quad-$ borrowing.

Usually $a=0$ or 1 , depending on whether the income source is controlled by the regional or central authorities. Mainly $a_{2}, a_{5}$ are equal to 0 and $a_{1}, a_{3}$, $a_{4}, a_{6}$ are equal to 1 , if the central and regional authorities participated in the given source, then $a=(0 ; 1)$ (Wallich 1982, p. 17).

The value of the coefficient of vertical imbalance equal to 0 informs us about the total financial control of the central authorities over the regional authorities, while the coefficient equal to 1 - about the total autonomy of the regional authorities in making financial decisions. It should be remembered that a high value of this coefficient is desirable, but its value is not a goal in 
itself. A value approximate to 1 is consistent with the principles of income division, but the total autonomy of the regional authorities is not the goal of any federation.

R. Bird and A. V. Tarasov proposed three ${ }^{5}$ gradually decreasing measures of vertical disproportion for each authority level (Bird and Tarasov 2002, pp. 7-8):

- unrestricted budget balances for the central, local, regional and subnational governments (sum of regional and local governments):

$$
S V I_{j}^{I}=\frac{(R+G)_{j}-(E+L)_{j}}{(E+L)_{j}} \cdot 100 \%,
$$

where: $S V I$ - budget balances,

$j$ - superscript indicates consolidated central government, regional, local or subnational government.

- budget balances, excluding net intergovernmental transfers between the government of interest and other levels of government:

$$
S V I_{j}^{I I}=\frac{(R+G)_{j}-N I G_{j}-(E+L)_{j}}{(E+L)_{j}^{N T}} \cdot 100 \%,
$$

where: $N I G-$ net intergovernmental grants,

$N T$ - superscript indicates that figures are net of intergovernmental transfers.

- budget balances, excluding intergovernmental transfers and intergovernmental net borrowing:

$$
S V I_{j}^{I I I}=\frac{(R+G)_{j}-N I G_{j}-I Z N_{j}-(E+L)_{j}}{(E+L)_{j}^{N T}+I Z N_{j}} \cdot 100 \%,
$$

where: IZN - intergovernmental net borrowing.

The above authors also proposed three coefficients of vertical imbalance (Bird Tarasov 2002, p. 8):

- intergovernmental transfer share in subnational government expenditure:

$$
C V I_{1}=\frac{N I G_{S N G}}{(E+L)_{S N G}^{N T}},
$$

where: $S N G$ - subscript indicates subnational level.

\footnotetext{
${ }^{5}$ Central, regional, local and subnational (regional plus local).
} 
In addition, a coefficient may be set for current and capital transfers:

$$
\begin{aligned}
& C V I_{1}^{\text {Cur }}=\frac{\operatorname{CurIG}_{S N G}}{(E+L)^{N T}{ }_{S N G}}, \\
& C V I_{1}^{C a p}=\frac{C a p I G_{S N G}}{(E+L)^{N T}{ }_{S N G}},
\end{aligned}
$$

where: $C V I^{C u r}$ - coefficient of vertical fiscal imbalance for current grants, $C V I^{C a p}$ - coefficient of vertical fiscal imbalance for capital grants,

CurIG - current intergovernmental grants,

CapIG - capital intergovernmental grants.

- intergovernmental transfer and intergovernmental net borrowing share in the subnational government expenditure:

$$
C V I_{2}=\frac{N I G_{S N G}+I Z N_{S N G}}{(E+L)^{N T}{ }_{S N G}}
$$

- share of subnational government expenditure that is not covered by the subnational government's own revenues:

$$
C V I_{3}=1-\left(\frac{(R+G)_{S N G}-N I G_{S N G}-I Z N_{S N G}}{(E+L)_{S N G}^{N T}}\right) .
$$

The higher the values of those indicators, the greater the vertical fiscal imbalance, thereby reflecting a higher degree of dependence of the subnational government on transfers and borrowings from the central government.

The World Bank, in turn, provides the following formula for calculating vertical imbalance (Fiscal Decentralization Indicators):

$$
C V I=\frac{G^{*}+G_{r}^{*}}{E_{l}+E_{r}},
$$

where: $G^{*}{ }_{l}$-transfers from other levels of government to local governments,

$G^{*}{ }_{r}$-transfers from other levels of government to regional governments,

$E_{l}$ - total expenditures of local governments,

$E_{r} \quad$-total expenditures of regional governments. 
According to the publications of the International Monetary Fund prepared by L. Eyraud and L. Lusinyan, a vertical imbalance emerges when there is a gap between own expenses (total expenses less disbursed transfers) and own income (total income less received transfers) at a given government level. Vertical fiscal imbalance is defined as the share of own expenses at subnational (regional and local) level which are not financed from own income (Italy... 2011, pp. 40-41; Eyraud, Lusinyan 2011, pp. 7-9). Based on their proposal the following formulas can be proposed:

$$
\begin{gathered}
C V I=1-\frac{R w_{S N G}}{E w_{S N G}}, \\
R w_{S N G}=R_{S N G}-G r_{S N G}-Z N_{S N G}, \\
E w_{S N G}=E_{S N G}-G p_{S N G},
\end{gathered}
$$

where: $R w_{S N G}-$ subnational level own revenue,

$E w_{S N G}$ - subnational level own spending,

$G r_{S N G}$ - transfer received by subnational level,

$G p_{S N G}$ - transfer paid by subnational level,

$R_{S N G}$ - subnational level revenue,

$Z N_{S N G}$ - subnational level net borrowing.

Then:

$$
\begin{gathered}
C V I=G d+D_{S N G}, \\
G d=\frac{G N}{E w_{S N G}}, \\
D_{S N G}=\frac{Z N_{S N G}}{E w_{S N G}},
\end{gathered}
$$

where: $G d$ - transfer dependency,

$G N$ - net transfer,

$D_{S N G}-$ subnational level deficit.

And finally:

$$
\begin{gathered}
C V I=1-\frac{\operatorname{dec} R}{\operatorname{dec} E} \cdot\left(1-D_{G G}\right), \\
\operatorname{dec} R=\frac{R w_{S N G}}{R_{G G}}, \\
\operatorname{dec} E=\frac{E w_{S N G}}{E_{G G}},
\end{gathered}
$$




$$
D_{G G}=\frac{E_{G G}-R_{G G}}{E_{G G}},
$$

where: $\operatorname{dec} R$ - revenue decentralization,

$\operatorname{dec} E$ - spending decentralization,

$D_{G G}$ - general government deficit,

$R_{G G}$ - general government revenue,

$E_{G G}-$ general government spending.

As shown by formula (18), L. Eyraud and L. Lusinyan claim that vertical imbalance depends on the lack of match between decentralization of income and expenses and the amount of deficit of government and local government institutions (Italy... 2011, p. 41; Eyraud, Lusinyan 2011, p. 9).

E. Ahmad and J. Craig propose to calculate vertical fiscal balance, based on which vertical fiscal imbalance can be calculated with the use of the following formula (Ahmad, Craig 1997, p. 75):

$$
C V I=1-\frac{R w_{S N G}}{E w_{S N G}} .
$$

D. J. Collins as well as R. D. Ebel and S. Yilmaz propose the following solution in order to calculate vertical fiscal imbalance for each level (Collins 2002, p. 130; Ebel, Yilmaz 2002, pp. 7-8):

$$
C V I=\frac{R w^{*}}{E w^{*}}
$$

where: $R w^{*}$ - particular level of government's own-source revenue, not

$E w^{*}$ - including transfers from other levels of government, particular level of government's own-purpose expenditures, not including transfers to other levels of government.

M. G. Rao and N. Singh propose four measures to calculate VFI (in \%) (Rao, Singh 2003, p. 103):

1. states' own current revenue to total current revenue.

2. states' current expenditure to total current expenditure.

3. states' own current revenue to states' current revenue.

4. states' expenditure (current plus capital) to total expenditure (current plus capital).

J. Rodden and E. Wibbels indicate the following VFI measure (Rodden, Wibbels 2002, p. 504): 


$$
C V I=\frac{G_{S N G}+u R_{S H}}{R_{S N G}},
$$

where: $u R_{S H}-$ revenue sharing receipts,

$G_{S N G}-$ subnational level transfers.

whereas R. Osterkamp and M. Eller propose the following formula to calculate VFI (Osterkamp, Eller 2003, p. 34):

$$
C V I=\frac{I G}{E_{S N G}} .
$$

S. Khemani calculates vertical financial imbalance by the formula (Khemani 2005, p. 36, 57):

$$
C V I=\frac{I G}{R_{S N G}} .
$$

As can be seen, the relevant literature has not developed a single formula for measuring vertical imbalance. The presented formulas, with multiple modifications, are based on Hunter's assumptions and the generally accepted assumption that vertical fiscal imbalance is the lack of match between income and expenses at different levels.

\section{RESEARCH RESULTS}

Since the methodology of R. Bird and A. V. Tarasov seems to be most developed and accommodating multiple diverse factors, including budget balances and deficit, which affect vertical fiscal imbalance, it served as the basis for calculating the said imbalance.

The measure of vertical disproportions measured as unrestricted budget balances - SVI $I^{I}$ - for a consolidated central, regional and subnational government, has nearly always assumed negative values. Only in the case of local government has this measure assumed slightly positive values in the following periods: 1984-1985, 1988-1989, 1998-2000, 2007-2008. In Germany in 2007-2008 this measure approached zero, which proves the balancing of income and expenses. Unfortunately, in 2009 an increased deficit occurred. Another approach to the balancing of income and expenses can be observed in the last year examined (Figures 1-4). 


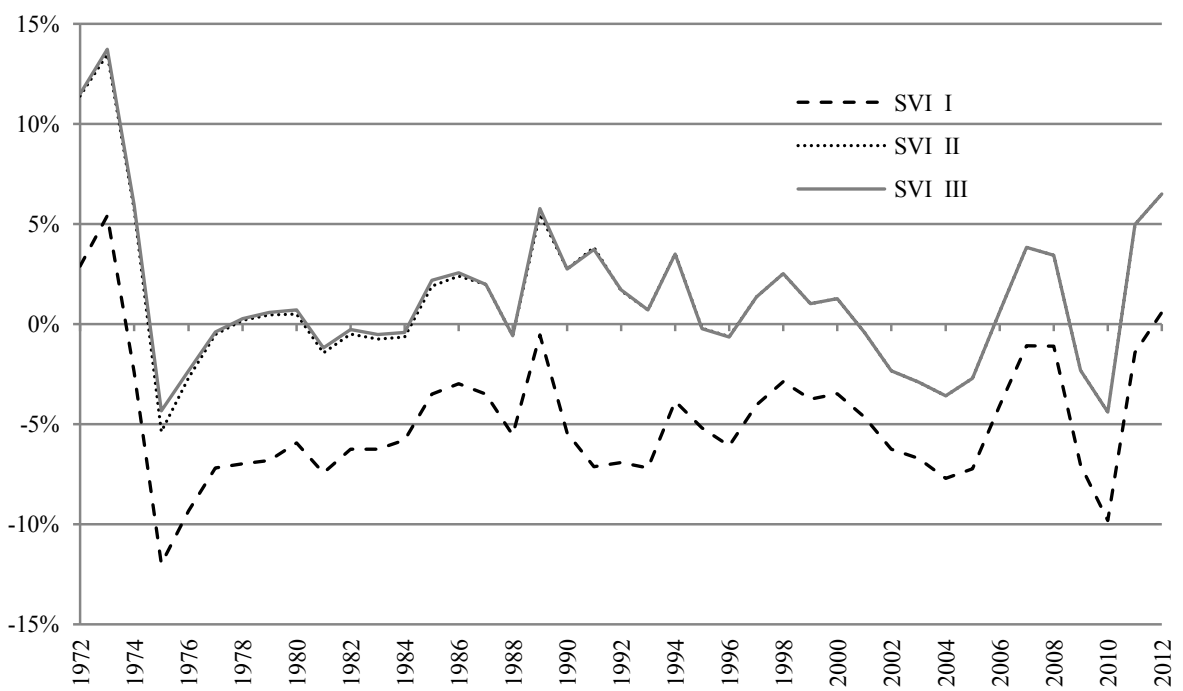

Figure 1. SVI II, III for consolidated central government in the period 1972-2012 (\%)

Source: own elaborated data based on Bird's and Tarasov's methodology (formulae 7-9) and IMF data [Historical... 2005; Government Finance...].

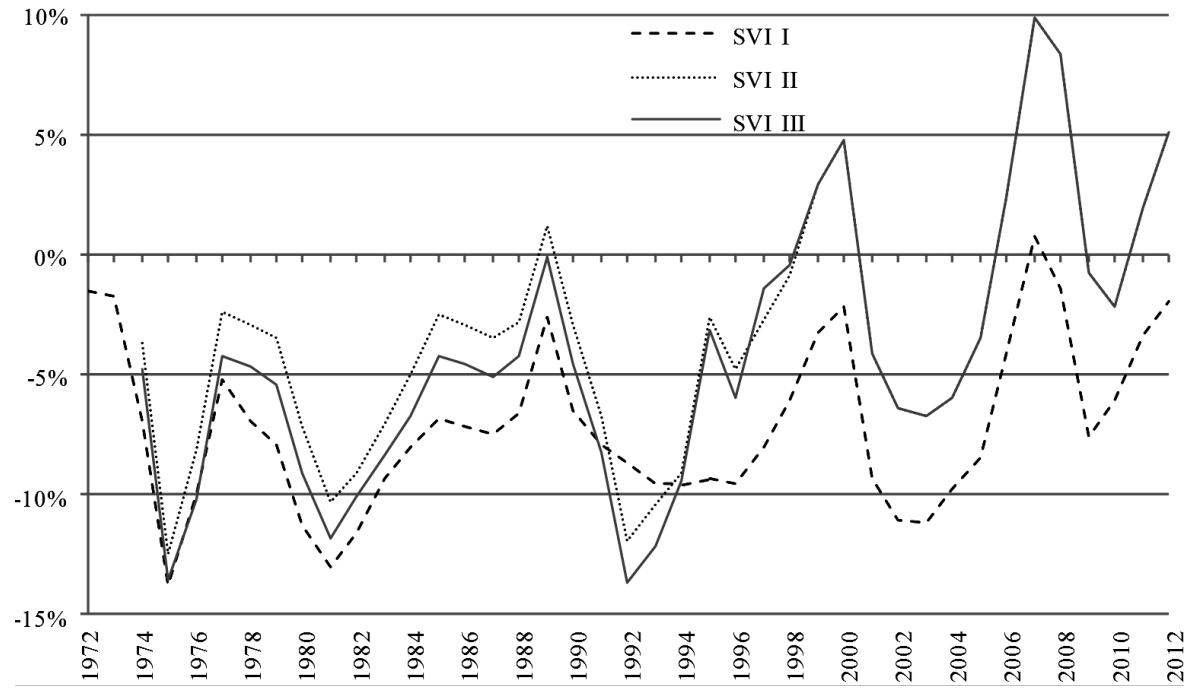

Figure 2. SVII,II,III for regional government in the period 1972-2012 (\%)

Source: own elaborated data based on Bird's and Tarasov's methodology (formulae 7-9) and IMF data [Historical... 2005; Government Finance...]. 


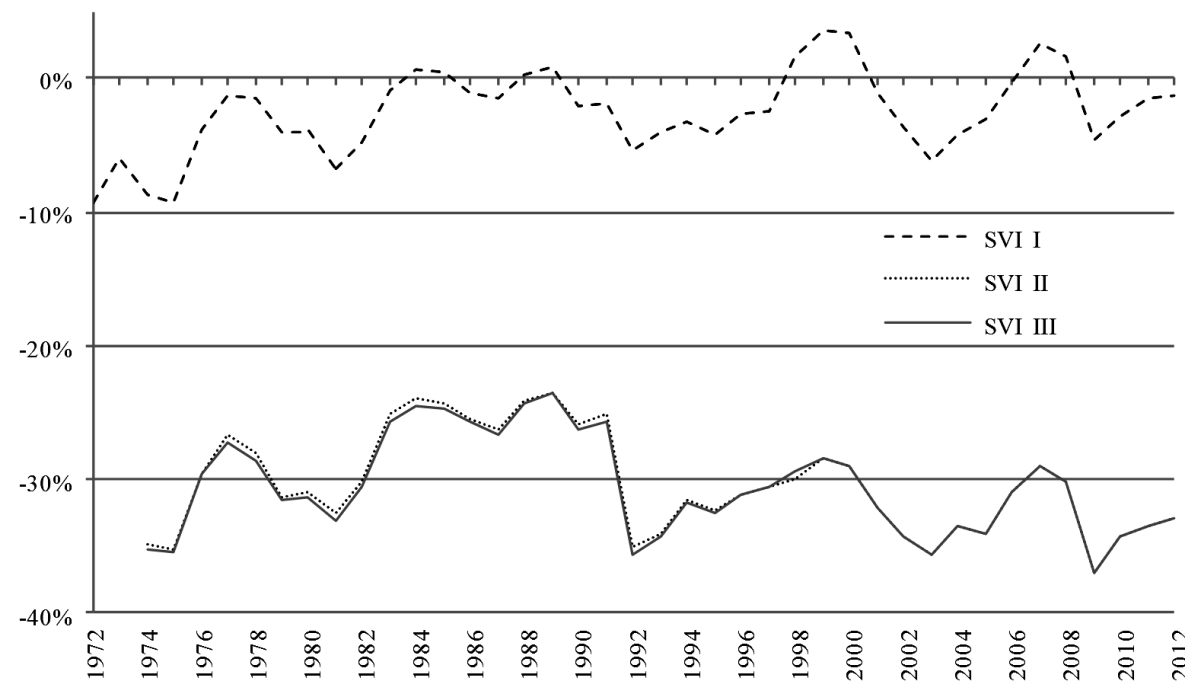

Figure 3. SVI, II, III for local government in the period 1972-2012 (\%)

Source: own elaborated data based on Bird's and Tarasov's methodology (formulae 7-9) and IMF data [Historical... 2005; Government Finance...].

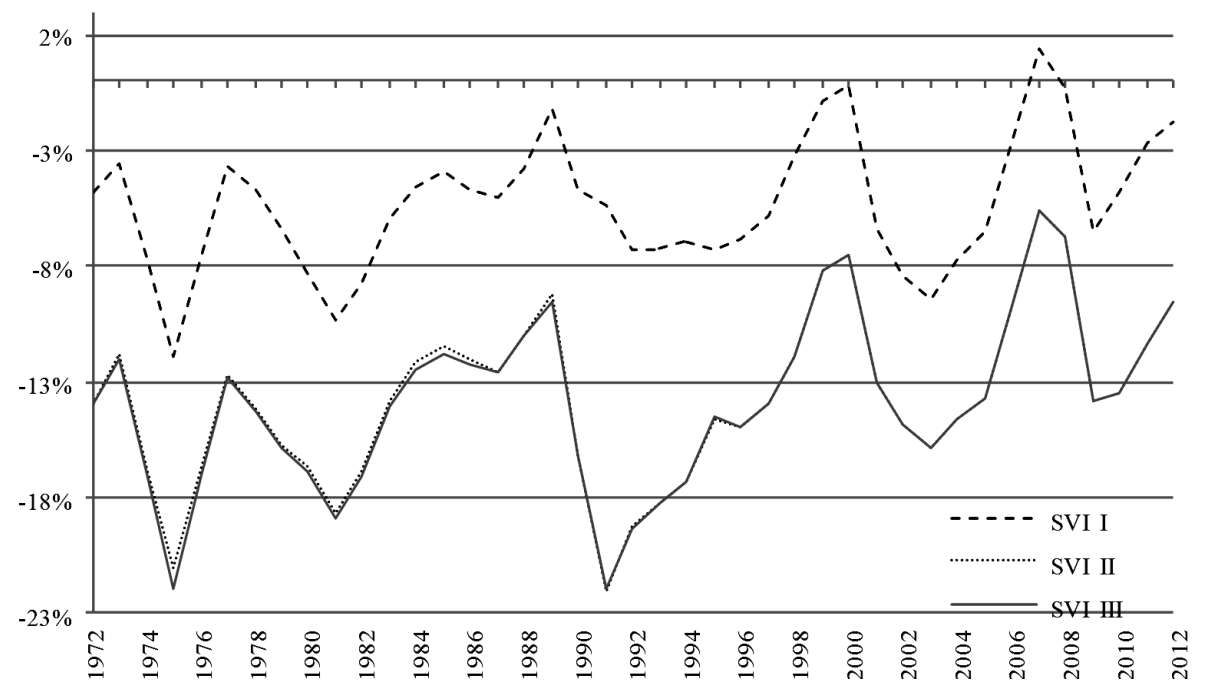

Figure 4. SVI II, III for subnational government in the period 1972-2012 (\%)

Source: own elaborated data based on Bird's and Tarasov's methodology (formulae 7-9) and IMF data [Historical... 2005; Government Finance...]. 
The measure of vertical disproportions measured as budget balances, excluding net intergovernmental transfers between the government of interest and other levels of government $-S V I I^{I I}$ shows that the largest deficit occurs at the local authority level. In Germany this amounted to $-35 \%$ (Figure 4) on average in the period 1974-2012. This indicates the large impact of intergovernmental transfers on the balancing of budgets of individual authority levels, in particular the local authority.

The measure of vertical disproportions measured as budget balances, excluding intergovernmental transfers and intergovernmental net borrowing - $S V I^{I I I}$ does not differ considerably from $S V^{I I I}$, which means that intergovernmental indebtedness does not significantly affect the budget balance (Figures 1-4).

The coefficient of vertical imbalance measured as the share of intergovernmental transfers in subnational expenditures $-C V I_{1}$ was higher in the late 1980s and early 1990s, when the unification of Germany took place. Outside this period it ranged at 0.063-0.094 (Figure 5). This means that VFI is not high and the degree to which the subnational government relies on transfers is low.

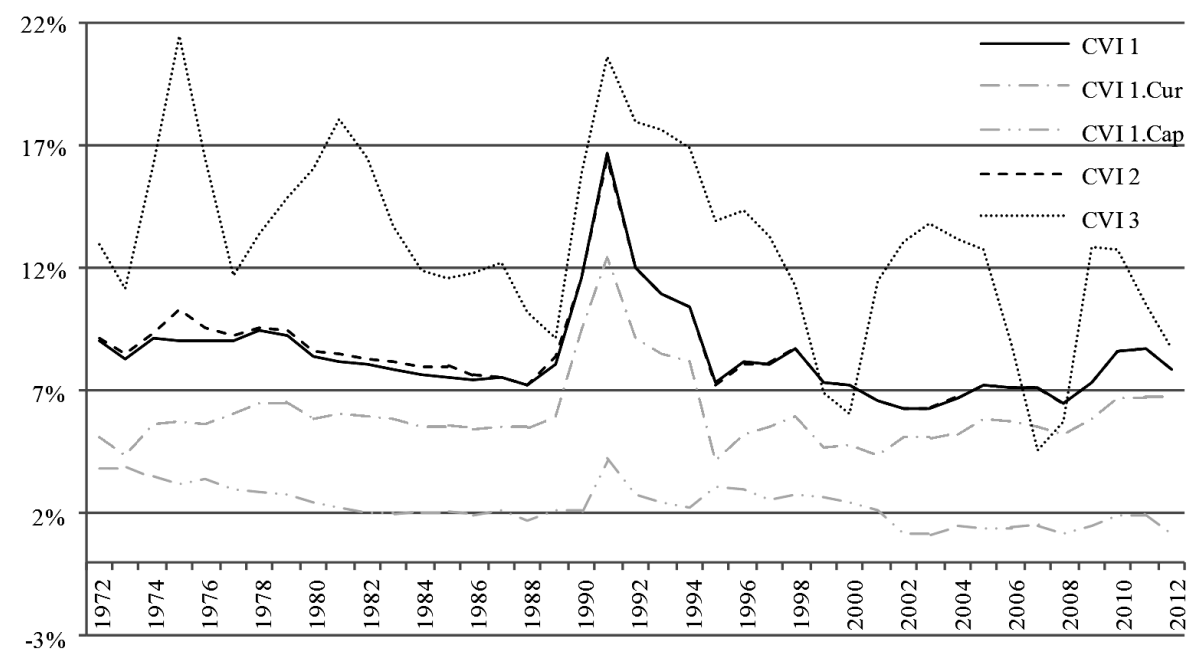

Figure 5. Coefficient of vertical imbalance $\mathrm{CVI}_{1}, \mathrm{CVI}_{1}{ }^{\mathrm{Cur}}, \mathrm{CVI}_{1}{ }^{\mathrm{Cap}}, \mathrm{CVI}_{2}, \mathrm{CVI}_{3}$ in Germany in the period 1972-2009 (\%)

Source: own elaborated data based on Bird's and Tarasov's methodology (formulae 10-14) and IMF data [Historical... 2005; Government Finance...]. 
The coefficient of vertical imbalance measured as the share of current intergovernmental transfers in subnational expenditures $-\mathrm{CVI}_{1}{ }^{\mathrm{Cur}}$ indicates also a low level of reliance of the subnational government on current transfers (Figure 5). The coefficient of vertical imbalance measured as the share of capital intergovernmental transfers in subnational expenditures $C V I_{1}{ }^{C a p}$ indicates also a very low degree to which the subnational government relies on capital transfers, whereby this reliance was greater during the time of unification and has increased in the recent years (Figure 5). The coefficient of vertical imbalance measured as the share of intergovernmental transfers and net intergovernmental indebtedness in subnational expenditures $-\mathrm{CVI}_{2}$ does not differ significantly from $C V I_{1}$ (Figure 5). The coefficient of vertical imbalance measured as the share of expenditures that are not covered by own income $-\mathrm{CVI}_{3}$ is slightly higher, which indicates a greater reliance of the regional and local level on transfers from the central level, in particular at the time of unification, as well as of the internal (2003-2005) and external crises (2008-2010) afflicting the German economy (Figure 5).

\section{CONCLUSION}

The public finance system, in particular in federations, is often very complex. The public finances of federations and federated states are not often placed within the same assumptions. This leads to differences between regions, both vertical and horizontal. The use of the presented measures helps identify those differences and permits developing mechanisms equalising those inequalities. It should be remembered that these measures may have certain drawbacks, and they mainly focus on certain specific values of income redistribution, thereby several measures should be applied in measurements and the obtained results should be compared.

The most frequently applied measures of vertical fiscal imbalance are the measures presented by A. Shah, R. Bird and A. V. Tarasov and the World Bank.

The coefficients of vertical imbalance $C V I_{1,2,3}$ calculated for Germany are low and therefore VFI is insignificant, which means, in turn, the small degree to which regional and local governments rely on transfers and borrowings from the central (federal) government. Only at the time of joining the eastern and western lands (Länder) was VFI higher, but it has been gradually reduced. 


\section{REFERENCES}

Ahmad, E., Craig, J., Intergovernmental Transfers, [in:] Ter-Minassian, T. (ed.) Fiscal Federalism in Theory and Practice, pp. 73-107. IMF, Fiscal Affairs Dept., Washington D.C. 1997.

Bird, R., Tarasov, A. V., Closing the Gap: Fiscal Imbalances and Intergovernmental Transfers in Developed Federations, Andrew Young School of Policy Studies, Georgia State University, Working Paper 02-02, Atlanta, March 2002.

Bitner, M., Cichocki, K. S., Finanse podsektora samorzadowego w wybranych krajach OECD $w$ latach 1999-2010 [Finance of the Self-Government Subsector in Selected OECD Countries in 1999-2010] „Samorząd Terytorialny”, nr 1-2, pp.5-71, 2012.

Boadway, R., Tremblay, J.-F., A Theory of Vertical Fiscal Imbalance, Queen's University, Queen's Economics Department Working Paper No. 1072, Kingston, 1-2006.

Collins, D. J., The 2000 Reform of Intergovernmental Fiscal Arrangements in Australia, in: International Symposium on Fiscal Imbalance: A Report, Canada: Commission on Fiscal Imbalance, Quebec 2002.

Ebel, R. D., Yilmaz, S., Concept of Fiscal Decentralization and Worldwide Overview, World Bank Institute WP 30346, 2002.

Eyraud, L., Lusinyan, L., Decentralizing Spending More than Revenue: Does It Hurt Fiscal Performance?, IMF Fiscal Affairs Department, WP/11/226, September 2011.

Fiscal Decentralization Indicators (www1.worldbank.org/publicsector/decentralization/ fiscalindicators.htm (18.01.2011)).

Government Finance Statistics Yearbook, IMF, Washington D.C., various editions.

Hettich, W., Winer, S., Vertical Imbalance in the Fiscal Systems of Federal States, "Canadian Journal of Economics", XIX, no. 4, pp. 745-765, November 1986.

Hunter, J. S. H., Vertical Intergovernmental Financial Imbalance: A Framework for Evaluation, "Finanzarchiv", Vol. 32, no. 3, pp. 481-492, 1974.

Hunter, J. S. H., Federalism and Fiscal Balance. Australian National University Press, Canberra 1977.

Historical Government Finance Statistics, Database and Browser on CD-ROM (1972-1989 in GFSM 1986 format), IMF, Washington D.C. 2005.

Khemani, S., Can Delegation Promote Fiscal Discipline in a Federation? Evidence from Fiscal Performance in the Indian States, Development Research Group, The World Bank, Washington D.C. 2005.

Kowalik, P., Measures of Vertical and Horizontal Fiscal Imbalance - An Attempt of Review, [in:] Cmela, R. P., Kruszyński, K. (eds.), Statistical Methods in Analyses of Economic Phenomena Under Integration and Globalization, pp. 277-297. Statistical Office in Lodz, Lodz 2012.

Kowalik, P., Pionowa i pozioma nierównowaga finansowa oraz system jej wyrównywania w państwie federalnym na przykładzie Niemiec i Stanów Zjednoczonych [Vertical and Horizontal Fiscal Imbalance and its Equalization in a Federal Country on the Example of Germany and the United States of America]. Wydawnictwo Uniwersytetu Ekonomicznego we Wrocławiu, Wrocław 2013. 
Lusinyan, L., Morsy, H., Zoli, E., Eyraud, L., Italy: Selected Issues, IMF Country Report no. 11/176, July 2011.

Martinez-Vazquez, J., Boex, J., Russia's Transition to a New Federalism, The World Bank, Washington, D.C. February 2001.

Martinez-Vazquez, J., Boex, J., The Design of Equalization Grants: Theory and Applications, Part One: "Theory and Concepts". World Bank Institute, Andrew Young School of Policy Studies, Georgia State University, Washington, D.C. 1999.

Osterkamp, R., Eller, M., How Decentralised is Government Activity? CESifo DICE Report $1 / 2003$.

Rao, M. G., Singh, N., The Political Economy of Center-State Fiscal Transfers in India, [in:] McLaren, J. (ed.), Institutional Elements of Tax Design and Reform, pp. 69-123. The World Bank, Washington D.C. 2003.

Rodden, J., Wibbels, E., Beyond the Fiction of Federalism. Macroeconomic Management in Multi-tiered Systems, "World Politics" 54, pp. 494-531, July 2002.

Schroeder, L., Smoke, P., Intergovernmental Fiscal Transfers: Concepts, International Practice and Policy Issues, [in:] Kim Y.-H., Smoke, P. (eds.), Intergovernmental Fiscal Transfers in Asia: Current Practice and Challenges for the Future, pp. 20-59. Asian Development Bank, Mandaluyong City, 2003.

Shah, A., Perspectives on the Design of Intergovernmental Fiscal Relations, World Bank Working Papers 726, Washington, D.C. July 1991.

Shah, A., Qureshi, Z., Intergovernmental Fiscal Relations in Indonesia. Issues and Reform Options, World Bank Discussion Papers 239, Washington, D.C. October 1994.

Shah, A., The Reform of Intergovernmental Fiscal Relations in Developing and Emerging Market Economies, Policy and Research Series 23 (13185), The World Bank, Washington, D.C. 1994.

Wallich, Ch., State Finances in India. Vol. 1. Revenue Sharing, World Bank Staff Working Papers 523, Washington, D.C. June 1982.

Received: July 2014, revised: July 2016 